慶應義塾大学学術情報リポジトリ

Keio Associated Repository of Academic resouces

\begin{tabular}{|c|l|}
\hline Title & A reticuloendothelial system activating glycan from the rhizomes of curcuma longa \\
\hline Sub Title & \\
\hline Author & $\begin{array}{l}\text { 友田, 正司(Tomoda, Masashi) } \\
\text { 潅田, 良子(Gonda, Ryoko) } \\
\text { 清水, 訓子(Shimizu, Noriko) } \\
\text { 金成, 美枝子(Kanari, Mieko) } \\
\text { 木村, 都(Kimura, Miyako) }\end{array}$ \\
\hline Publisher & 共立薬科大学 \\
\hline Publication year & 1990 \\
\hline Jtitle & $\begin{array}{l}\text { 共立薬科大学研究年報 (The annual report of the Kyoritsu College of } \\
\text { Pharmacy). No.35 (1990. ),p.37-37 }\end{array}$ \\
\hline JaLC DOI & \\
\hline Abstract & \\
\hline Notes & 抄録 \\
\hline Genre & Technical Report \\
\hline URL & https://koara.lib.keio.ac.jp/xoonips/modules/xoonips/detail.php?koara_id=AN00062898-0000003 \\
\hline $5-0037$
\end{tabular}

慶應義塾大学学術情報リポジトリ(KOARA)に掲載されているコンテンツの著作権は、それぞれの著作者、学会または出版社/発行者に帰属し、その権利は著作権法によって 保護されています。引用にあたっては、著作権法を遵守してご利用ください。

The copyrights of content available on the KeiO Associated Repository of Academic resources (KOARA) belong to the respective authors, academic societies, or publishers/issuers, and these rights are protected by the Japanese Copyright Act. When quoting the content, please follow the Japanese copyright act. 


\title{
A Reticuloendothelial System Activating Glycan from the Rhizomes of Curcuma longa*
}

\author{
* Masashi Tomoda, Ryōko Gonda, Noriko Shimizu, Mieko Kanari \\ and Miyako KIMURA
}

友田正司，権田良子，清水訓子，金成美枝子，木村 都

From the hot water extract of the rhizomes of Curcuma longa, a glycan, named ukonan $\mathrm{A}$, has been isolated by fractionation on DEAE-Sephadex A-25 followed by chromatography on Con A-Sepharose and Sephacryl S-300 columns. The glycan showed remarkable reticuloendothelial system potentiating activity in the carbon clearance test.

The glycan was composed of a polysaccharide (92.7\%) and a peptide moiety $(7.3 \%)$. The polysaccharide was composed of L-arabinose, D-xylose, D-galactose, D-glucose, L-rhamnose and D-galacturonic acid in the molar ratio of 12:4:12:1:4: 10. Gel chromatography gave a value of $1.1 \times 10^{5}$ for its molecular mass. It gave a single band on PAGE, and a single peak on gel chromatography.

Chemical and spectroscopic studies established that the minimal unit of the polysaccharide is composed of twelve terminal $\alpha$-L-arabinofuranose, four $\alpha-1,5$-linked L-arabinofuranose, eight $\alpha$-1,3-linked L-arabinopyranose, one $\beta$-1,4-linked $D$ xylopyranose, seven $\beta$-3,4-branched $D$-xylose, nine terminal $\beta$-D-galactose, three $\beta$ 1,3 -linked $\mathrm{D}$-galactose, three $\beta$-1,6-linked $\mathrm{D}$-galactose, nine $\beta$-3,6-branched $\mathrm{D}$ galactose, one terminal $\alpha$-D-glucose, one $\alpha$-1,4-linked D-glucose, two $\alpha$-1,2-linked Lrhamnose, six $\alpha$-2,4-branched L-rhamnose and twenty $\alpha$-1,4-linked D-galacturonic acid residues.

* 本報告は Phytochemistry, 29, 1083-1086（1990）に発表. 